\title{
Generation Who, What, Y? What You Need to Know About Generation Y
}

Received (in revised form): April 8, 2004

\section{Leslie A. Goldgehn}

Leslie A. Goldgehn is a tenured Professor of Marketing at the School of Business and Administration at the University of San Francisco. She received her Ph.D. from Northwestern University where she studied with Dr. Philip Kotler. Prior to completing her doctoral studies she worked as a consultant with KPMG Peat Marwick and the Management Analysis Center. She often consults with universities and colleges, small businesses and nonprofits in the areas of marketing, branding, recruitment, team building, leadership development, and organizational design. As a Fulbright Scholar, she spent a semester teaching, conducting research, and consulting in the Czech Republic. Dr. Goldgehn is the Founder and Director of CollegeMatters, a college admissions advising and coaching business. She assists high school and college transfer students and their families through the college research, evaluation, selection, application preparation, and decision process. Her mission is to help students achieve their academic and personal potential.

\begin{abstract}
Generation Y wants to know why! Today's youth are curious, they want the facts, they want the hard data, and most of all they want the truth. Advertisements and creative marketing tactics do not easily sway this group. They do their research before they believe most things they hear and see. Purchasing behaviors of Generation Y show that the group is extremely brand conscious as well as brand loyal. Consumers in this group are willing to pay the price for brand name goods as long as they find value and quality in the product. With this unique generation comes an exceptionally fascinating approach to higher education. College is no longer just a place students
\end{abstract}

Author's Contact Address:

Leslie A. Goldgehn, Ph.D.

University of San Francisco

School of Business and Administration

2130 Fulton Street

San Francisco, CA 94117-1080, USA

Phone: + 14159245062

Fax: + 14159245063

Email: goldgehnl@usfca.edu go to further their knowledge; in fact, it's now fashionable, hip, cool, and quite image-defining. Traditional structured forms of communication do not work well with this generation. They like to experience things themselves and figure out the answers rather than being told. They desire the freedom to choose and do, as they desire. When communicating with Generation Y colleges need to be real, be raw, be relevant, and focus on establishing relationships. The purpose of this paper is to better understand Generation Y, gain a sense of what criteria are important to them in choosing a college, and to determine what implications this has for colleges and universities.

Keywords: marketing, branding, Generation $Y$, recruitment, admissions, bigher education

\section{Background}

Developing brand identity is critical to the success of institutions of higher 
education. This has never been truer than with the onslaught of Generation Y into the college ranks. With this unique generation comes an exceptionally fascinating approach to higher education. College is no longer just a place students go to further their knowledge; in fact, it's now fashionable, hip, cool, and quite image-defining.

The purpose of this paper is to better understand Generation Y, gain a sense of what criteria are important to them in choosing a college, and to determine what implications this has for colleges and universities.

This paper is based on a thorough literature review of articles and books relating to Generation Y, college admissions, marketing, and branding. In addition, questionnaires were administered to high school juniors and seniors at two high schools (one private and one public) to learn more about their preferences, beliefs, and ideas about colleges and their college decision-making process.

Finally, questionnaires were administered to college students at a private university to determine what criteria they used in their college decisionmaking process, how they assess those criteria now that they are enrolled in college, and how branding and the unique characteristics of their generation influenced their college choice. A total of 300 of the 374 questionnaires were determined to be usable.

\section{Gen Y: Who Are They and How Did They Get that Way?}

Generation Y wants to know why! Today's youth are curious, they want the facts, they want the hard data, and most of all they want the truth. Advertisements and creative marketing tactics do not easily sway this group. They do their research before they believe most things they hear and see. They do not want to "be like Mike." Present yourself as a credible source and offer them avenues for investigation, however, and you'll likely win the hearts and minds of this unique generation.

Generation $\mathrm{Y}$ is a group of more than 70 million, comprised of teens and young adults born between 1981 and 2000. They are the children of the Baby Boomers and, at a young age, members of Generation $Y$ are already causing the world to take them seriously. These socalled "Millennials" are privileged in a way different from any generation before them. Raised during a period when the world has welcomed and protected children, many believe the group will grow-up to be "doers" and "achievers" and thus a powerhouse generation. They are happy, wholesome, accepting of all peoples, and the first generation in which females not only have equal rights, but they are acting on them and making names for themselves. ${ }^{1}$

Generation Y has no reason to think woman's equality is anything special; to them, it has always existed. Today's children have grown up with and continue to grow up with money to spend, their worries limited to little beyond the war in Iraq, and a plethora of "convenience devices" such as cell phones, pagers, digital cameras, and ATM cards.

While Generation $\mathrm{Y}$ is enormous in number and more affluent than any previous group, these are only two of many characteristics that make them unique. They are also better educated than their elders were at the same age and they comprise an extremely heterogeneous group in a racial and socioeconomic context-more so than any generation before them. One out of every 35 Millennials are of mixed race and over 30 
percent are of Hispanic descent.

Furthermore, the revolution in technology played a significant role in shaping Generation Y. Millennials were raised from birth on digital technology. According to a study done by Forrester Research, more than 60 percent of them are online chatting on AOL's Instant Messenger, checking email, and/or browsing sites for fun. As experienced internet users, they have great expectations for websites-almost zero tolerance for sites that are not well-developed or debugged, and though they appreciate flashy technology, if it does not add value to their experience on the site they find it annoying. ${ }^{5}$ Most of their recreation time is also spent searching the web.

\section{Is Generation Y a Significant Consumer Group?}

Despite their young age, Millennials are quite sophisticated shoppers and they are not afraid to spend money on quality brands. In fact, recent estimates suggest that this group spends between $\$ 100$ billion and $\$ 450$ billion a year.

In general, the members of Generation Y are incredible consumers. A glance at a few recent statistics illustrates this quite well:

- Teenagers spent $\$ 155$ billion last year,

- On average, they spend $\$ 84$ per week, $\$ 57$ of which comes from money given to them by their parents,

- 66 percent have savings accounts,

- 22 percent have checking accounts,

- 18 percent own stocks and bonds,

- 8 percent own mutual funds. ${ }^{2}$

Millennials display very mature financial and purchasing behaviors. One should remember, however, that members of Generation Y, though they have money to spend, look for value and quality in their purchases. They do not spend money just to spend it.

\section{What Value Do They Place on Brands and Branding?}

Purchasing behaviors of Generation Y show that the group is extremely brand conscious as well as brand loyal.

Consumers in this group are willing to pay the price for brand name goods as long as they find value and quality in the product. With more money to spend than any previous young generation,

Millennials have no reason not to buy the exact brand they want. In fact, teens are spending 50 percent more per week today (2003) than they did 10 years ago. ${ }^{3}$

Furthermore, data shows that once Millennials find a brand they like, it takes a great deal of persuading to get them to deviate. $^{4}$

Their loyalties are amazingly strong and thus colleges that wish to develop a strong consumer base among Generation Y members need to target them early. Their loyalties and preferences, however, do not come out of nowhere. Advertisements, peers, and family members play a great part in shaping Millennials' beliefs and attitudes about individual brands.

\section{What are Their Values? What do They Want?}

\section{Friendship}

Millennials place a great deal of emphasis on friendships, but such relationships must center on understanding, acceptance, and respect. ${ }^{5}$ Though individuality is significant and should not be underestimated, "fitting in" is of equal importance to them. They feel very strongly about living up to the expectations of their peers and their communities. 


\section{Technology/money}

Growing up with an overabundance of technological gadgets, Millennials are undoubtedly the most materially spoiled Generation Yet. However, this in no way implies that these youth never get bored. In fact, they express boredom as the number one problem they try to avoid in their lives. ${ }^{6}$ Millennials rate the importance of money much lower than do previous generations.

\section{Happiness and moral purpose}

This group feels that, in the working world, training, management style, flexibility, staff activities, and nonfinancial rewards are more important than salary. ${ }^{7}$ However, they do have a tendency to splurge in the consumption/ purchase of leisure and entertainment products.

They want to live fun and exciting lives filled with many great friendships, they seek some sort of rewarding purpose out of life, and most express a desire to find a spiritual meaning in their lives.

They place significant emphasis on ethics. Millennials also love to be involved; they find great pleasure and satisfaction in volunteering for numerous causes.

Above all else, Generation Y seeks happiness. The key to such happiness, as evidenced by a recent Louis Harris Poll, is close family relationships. ${ }^{8}$ Such feelings likely stem from the fact that 50 percent of today's youth in the USA come from divorced families. As such, closeness, according to this generation, demands that families work hard to stay intact and when parents do divorce, they remain friends and work at keeping the feel of family in the home.

\section{Teamwork}

Many Millennials also find pleasure through teamwork and thus often involve themselves in sports programs. They like to play and study in groups, and advertisements they find most appealing display groups of youth interacting as well. One of their most recent favorites is the Gap advertisement that features dancing teenagers dressed alike. ${ }^{9}$

\section{A structured environment}

Millennials also tend to have a great deal of structure and order in their lives. At both public and many private schools, they grew up wearing uniforms, taking achievement test after achievement test, and seeing metal detectors and drug dogs at their high schools. Furthermore, their participation in sports programs and groups outside of school require them to schedule their days carefully so as to allow room for homework and time at home. ${ }^{10}$ As such, Millennials are accustomed to leading organized lives bound by rules. As they enter college however, it appears members of Generation Y seek a life of greater freedom to do as they please rather than one bound by rules and regulations. Typical Millennials do not desire to rebel against the system, but simply (upon reaching college) wants to spend their time doing whatever they want whenever they want.

\section{Who/What Influences Generation Y the Most? And over Whom do They have Influence?}

\section{The importance of mentors}

Members of Generation Y, though extremely influenced by their peers and the values of their community, express a great desire for guidance and direction from someone they feel they can trust. As Mark McCrindle puts it, "This generation wants guidance in the form of a navigator, not a street directory." 11 
So-called "street directories" provide guidance for specific types of success (financial, relationship, etc). Millennials simply want guidance on what direction to take and/or what path to follow. They want role models and mentors who have been in their exact position before and can offer some assistance.

\section{Being "tipped"}

Their desire for a mentor or role model, however, should not lead one to think that Millennials need their hands held. In fact, today's youngsters merely need someone to "tip" them, as Malcolm Gladwell would say, in the right direction. ${ }^{12}$ In his book, The Tipping Point, Gladwell reminds readers that no matter what new technological information is available, or what the latest innovation may be, human beings will forever remain social beings. As such, humans are in constant interaction with one another, influencing and being influenced. Thus, even though Generation $\mathrm{Y}$ is accustomed to the most advanced technology available, they nevertheless remain influenced by those around them. Mentors then, according to Gladwell's theory, need two things in order to be effective with their Millennial mentees: experience in the specific field/area and an influential persona that draws people to them. Such a person can offer the smallest piece of advice or direction and successfully "tip" a Millennial down the right path, and may even create a word-ofmouth epidemic with his or her small token of advice that sends numerous members of Generation Y down the correct path.

\section{"Parents are cool"}

Generation Y appears to be a very societyand community-oriented group.

Accordingly, decisions they make are most influenced by their peers and those around them. The experiences of their friends and ideas they share with one another tend to be the strongest influencers on this group. Millennials do not look to authority figures or core values when making decisions, but rather they work to make choices that align with community values and that are approved by their peer group. ${ }^{13}$ In viewing their parents as "friends" rather than "authorities," members of Generation Y look to their parents for advice and suggestions and place high value on their input. MTV research actually reports that today's youth no longer sees it as "us versus them" (meaning kids versus parents), but instead believe "parents are cool." 14

While certain things and people can influence Millennials, they, in turn, are a very influential group themselves. In fact, they play a very prominent role in the purchases of their parents, to include luxury items and household goods. A recent General Motors campaign provides a prime example of this truth. The automobile company advertises cars to young "backseat consumers" in such magazines as Crayola Kids. ${ }^{15}$

\section{How Does Generation Y View Higher Education?}

Though members of Generation Y feel very strongly about the importance of a college education, they view it differently than previous generations. Their strong desire to live on-campus throughout their college days (versus off-campus as previous generations preferred) demonstrates one significant difference. According to McCrindle, Millennials have a very shortterm focus; they have not set expectations or plans for themselves beyond college. ${ }^{16}$ Universities therefore, must find a way to make themselves desirable to this group 
comprised of youth who do not know if they want to be a CEO, an educator, a politician, an at-home $\mathrm{mom} / \mathrm{dad}$, or a lifelong kid. One thing Millennials are certain of, however, is that they will work to live unlike their parents who live to work. $^{17}$

Generation $\mathrm{Y}$ is a determined and motivated group that overwhelmingly believes that academic achievement is the ticket to acceleration in life. ${ }^{18}$ They see college as an opportunity for growth intellectually and spiritually.

\section{Has Higher Education Become a Fashion Item?}

A plethora of websites and magazine publications now exist that feature the fashionable and trendy aspects of college and college life, as well as list the coolest schools and/or the schools with the best "brand name."

One such site that has become extremely popular with Millennials is <www.colleges.com/Umagazine〉. This site simply speaks about the latest trends on college campuses, offers the "hottest gossip," and also provides helpful/ informational articles on various universities across the United States. The site periodically features a different school offering lesser-known colleges a great chance to make students aware of their existence as well as what they have to offer. The site also lists the top school in virtually every category imaginable from most men on campus, easiest school for admission, best cheerleading squad, most snowfall, and tallest dorm building, just to name a few.

As well as websites, magazines solely focusing on college life are now readily available, and even one of the most popular fashion magazines with teenage girls, Seventeen, often includes numerous articles on universities. Every few months,
Seventeen includes a section they call "College Chat," which profiles a different university each time and showcases a few female students at the school. The young women describe their school's social scene, the coolest bars and cafes, where the best shopping is, and how handsome the male population is or is not. While members of older generations may find this a bit ridiculous, such factors have great potential to "tip" a student's decision one way or another.

Furthermore, Seventeen has exploited the newly conceived fashionable aspect of college. The magazine helps universities promote and showcase their brands while simultaneously informing teenage girls of various schools' images. The October 2002 issue of the magazine featured the "100 Coolest Colleges" based on criteria such as fraternity parties, professor involvement, campus safety, and what school has the best shopping nearby. ${ }^{19}$ Seventeen also provides its readers with very important information regarding financial aid, class sizes, and acceptance policies.

\section{How Should Your College Communicate with Generation Y?}

Traditional structured forms of communication do not work well with Generation Y. They like to experience things themselves and figure out the answers rather than being told. They desire the freedom to choose and do, as they desire.

\section{Establish a relationship}

Colleges should keep in mind four key elements when communicating with Generation Y: be real, be raw, be relevant, and focus on establishing relationships. In order to be real, communication styles as well as communicators must be credible. 
Spontaneous, interactive, and open forms of communication define the concept of being raw. Millennials do not like receiving practiced speeches. Additionally, the message content must be relevant to their generation. Communicators should thus keep in mind that this is a visually and technologically educated and entertained group. Finally, communicators can establish relationships by being open, working to understand this generation, expressing a genuine interest in them, and talking to them rather than down to them.

\section{Repeat the message}

Another crucial point those seeking to communicate with Generation Y must keep in mind is the notion of repetition. Millennials share ideas with each other at malls, on cell phones and pagers, through text messaging, instant messaging, as well as in chat rooms. Someone wishing to communicate with them therefore must obtain a means of sending them the same message via each of these channels. Reliance on only one is insufficient.

\section{Interact and discover}

Interactivity and a sense of discovery are two communication practices that appear to have great effects among Generation $Y$ members. Interaction that works best is that with some sort of purpose. For instance, Millennials love surveys, questionnaires, and polls that will be reported in future articles or used for research. In terms of discovery, members of this group like to feel like they uncovered something. Communicators, therefore, would likely fare well if they allow Millennials to feel as though they discovered something, found the answer themselves, and/or thought of a new idea. Colleges should keep this in mind. While it is vital to market a university and make people familiar with the name and brand of the school, today's youth want to feel as though they found the college rather than the college found them.

\section{Image, image, image}

Millennials are hip and cool and seek advertisements and publications that give off a cutting-edge image as well. ${ }^{20}$ They want attention and they want to feel important. Anyone hoping to reach this group must take such concepts into consideration.

\section{Connect at an early age}

It makes sense then that anyone wanting to develop a lasting relationship with Millennials should make every effort to do so at an early age. Colleges, therefore, enter the game much too late if they wait until children reach high school to begin sending them material. Today's high school students will be much more interested in a college if they became familiar with the institution at a young age and in some way the school worked to foster relationships with these youth over the years.

The University of California at Berkeley does an incredible job at developing a relationship with youngsters via summer camp. Cal's summer camp, "The Lair of the Bear," provides children of all ages with a week of fun and games and ingrains in them a positive and favorable image of the university. Indeed, many Lair campers become friends in elementary school, continue to go to camp together throughout high school, and then end up at $\mathrm{Cal}$ together. As this example proves, strong summer camps can be extremely effective.

Other avenues of connecting early with today's youngest generation include selling or giving away t-shirts and sweatshirts with your school's name across the front; 
sending out news, updates, and schedules about the school's sports teams; offering courses on campus for youth; and offering/sponsoring summer camps. These youth can be, and like to be, approached by marketers at an early age. ${ }^{21}$ In fact, though still young in age (the oldest of this generation being 22 today), their behavior leads researchers to find them an extremely brand loyal group.

\section{Don't forget the internet}

The internet offers itself as a do-or-die situation for colleges, to grab the attention of Millennials and pull them in or to turn them off completely Maintaining a great, interactive website and/or sending them email that includes a direct link to the school's website are two excellent ways of continuing to build relationships with Millennials. ${ }^{22}$

\section{What Can You Do to Attract this Generation?}

\section{Provide a value-added education}

A significant number of colleges have already taken steps to better reach the Generation Y market. Examples of recent actions include the development of contemporary "value-added" academic offerings, off-campus learning programs, apartment-styled dorms, and blending information technology and access to the internet with classroom instruction. ${ }^{23}$ However, the challenges universities today face with regards to this new generation are endless. Even those who have taken some preliminary action are far from mastering the needs and wants of Millennials.

Some of the greatest challenges include: managing emerging IT needs, service needs, student discounting, diverse student bodies, and consumer-oriented services as well as offering better food options on campus and more flexible meal plans. Colleges also must develop improved learning environments, find ways to balance costs of old and new services, and stay current with the latest in internet technology. ${ }^{24}$

\section{Upgrade your residence halls}

The first wave of Millennials currently comprise the majority of the United States college student population, and the trend seems to be living on-campus in the residence halls. Millennials seem to prefer the dorms much more than members of Generation X did, if for no other reason than that they place greater value on friendships and peer interaction. The dorms, most Millennials are finding, are the best place to make new friends and develop strong bonds. ${ }^{25}$ Other reasons for their desire to live in the dorms include high-speed internet access, great food options both at on-campus eateries and in the cafeteria, and the fact that few dorms today have the curfews or rigid rules that were so prevalent in the past. ${ }^{26}$

\section{Know your consumer}

It has been said that marketers trying to build a brand in the college market need to throw away all recollections of their own college days. What Boomers and Xers found attractive and appealing is likely not going to coincide with Millennials' preferences. Colleges should begin their efforts to reach Generation Y by performing a market analysis, determining its brand and what it stands for, deciding how to best position its brand, and finally, conducting "on the move media." On the move media consists of sending out your message/placing advertisements offline, online, on campus, and via grassroots efforts. Universities should also remember that in today's society life moves at a fast pace-what is "hot" today 
might very well be "lame" tomorrow. Thus schools should make a continuous effort to improve, enhance, and alter their image as trends come and go and Millennials adopt new preferences.

\section{Develop a branding strategy}

Researching the brands Millennials find most attractive today would also be a great strategy for universities. From learning about the marketing and branding approaches of the current hot brands in the Millennial mindset, colleges can create similar tactics and strategies for reaching the Generation Y consumer. For example, brands such as Abercrombie \& Fitch, Jamba Juice, Hard Candy, Skechers, and Steve Madden, LTD have figured out how to create loyalty and affinity amongst today's youth in the United States.

Accordingly, Millennials point to the above brands as some of their favorites. These brands have combined sexy images with proven marketing strategies, and they offer a product that has value, style, personality, and-maybe most importantly-is unique.

\section{Nurture strategic contacts}

Other important efforts universities can make include planning strategic first contacts with Millennials. Contact must be made very early in a child's life (i.e., during elementary school and junior high) and a substantial connection needs to be made. After the initial interaction, schools would do well to create fun, creative, and new things to keep their name on the minds of their potential future students. Examples might be sending an email and/ or regular mail, placing a banner ad on popular websites of youth, sending a text message to their cell phones or providing them with a number at which they can text you or vote on something or express their opinion. Millennials love to have their voice heard. Advertising in fashionable magazines would surely be worth pursuing as well.

\section{Remember that marketing means student satisfaction}

In terms of administration procedures, colleges must adapt them as well. Efforts should be made to create a marketing department if there is not one already, and put great resources into ensuring that the marketing and admissions departments work hand in hand. Sufficient funds must be allocated to reaching the Generation $\mathrm{Y}$ consumer as otherwise your school will get left behind by others that actively pursue modern tactics to attract the next wave of students.

\section{Make your admissions strategies "cutting edge"}

The admissions department cannot simply be reactive. It should instead focus on being proactive and coordinating efforts with the marketing department to pursue potential students. The two departments might plan college visits for Millennials (of all ages, not just high school seniors) as well as make efforts to go out themselves and visit high schools and even junior high schools. Visits need highlight more than the campus and the academic facilities as Generation Y wants to know about the local hot spots, Greek Row, neighboring parks, shopping, and so forth.

In attempts to be "cutting edge," recruitment departments might send representatives to shopping centers, concerts, or heavily trafficked dining locations. The school's name and brand should be seen in venues that Millennials favor and find cool. Activities, sports, and festivals on campus should be promoted. Colleges can even establish youth fan 
clubs by designating small sections of stadiums to such a club and selling such tickets at a slightly discounted price.

\section{Do not forget the all-important website}

Lastly, colleges must put forth significant energy and resources in making their school website the hottest thing around. Websites should be interactive, offering live chat rooms and many relevant links to click on. Sites must offer potential students something unique, something of value, and/or something with personality. The average Millennial needs some reason to be interested in the school's siteenough to visit it and thoroughly check it out. Colleges might find it advantageous to highlight ideas and concepts that youth find important such as sports, movies filmed on campus, fashion, beaches, famous alumni, spiritual/religious groups, and volunteer organizations. Such things will not only increase the number of Millennial visitors to a college site, but will also lengthen the amount of time spent on the site.

\section{Conclusions}

The Millennials pose new and intriguing marketing challenges for institutions of higher education. These children of baby boomers are sophisticated consumers, savvy about advertising and public relations, community oriented, racially diverse, technologically astute, and view college as a growth experience and even a fashion statement. This places a significant challenge upon admissions, marketing, and public relations departments of colleges and universities to know their constituency. Just because something worked in the past, it does not mean it will work with Generation Y. Communication with this generation needs to be on their terms and focused on relationships. College students and their parents, more than any previous generation, will be going into significant debt to be able to pay tuition. Because of state school cutbacks and dramatic raises in tuition and fees (look no further than California) and the rising relative cost of private school education, this generation will finish school with a high debt load. This makes them even more discerning consumers.

Generation Y looks to their mentors, their parents, and significant others to "tip" them in the right direction in life and in their choice of a college. They wish to establish a relationship, interact and discover, and-more than previous generations-are concerned with image and brand name. Generation Y asks, "Who, What and Why," and your college needs to have the answers.

\section{References}

1. K. Lamancusa, "Youth trends" <http:// www.lamancusa.com/trends_html/ trends_articles.html>.

2. Stephen Merritt, "The Millennials: A Perspective on America's Next Generation" <http:// www17.homepage.villanova.edu/stephen.merritt/ NotreDame.htm>.

3. Promar International, "Generation Y: Winning snack strategies," <http:// www.promarinternational.com/Brochures/ GenYwsamples.pdf>.

4. A. Fishman (1998), "Generational marketing: Reaching the hearts and minds of consumers" <http://www.circman.com/ar/ marketing_generational_marketing_reaching>.

5. Mark McCrindle, "Understanding Generation Y" <http://www.apnz.ac.nz/index.htm?http:// www.apnz.ac.nz/conferences/past_conferences/2002 APNZ/MarkMcCrindle01.htm>.

6. Ibid.

7. Ibid.

8. Merritt, "The Millennials," op. cit.

9. Lamancusa, "Youth trends," op. cit.

10. Ibid.

11. McCrindle, "Understanding Generation Y," op. cit.

12. M. Gladwell (2000), The Tipping Point: How Little Things Can Make a Big Difference, Little Brown, New York. 
13. McCrindle, "Understanding Generation Y," op. cit.

14. Merritt, "The Millennials," op. cit.

15. Lamancusa, "Youth trends," op. cit.

16. McCrindle, "Understanding Generation Y," op. cit.

17. Ibid.

18. Ibid.

19. "100 coolest colleges" (2002), Seventeen, October.

20. Fishman (1998), “Generational marketing," op. cit.

21. Ibid.

22. Ibid.
23. Ibid

24. Ibid.

25. A. W. Corey (2001), "The student boom" <http:// abcnews.go.com/sections/us/DailyNews/ studentboom000825.html>.

26. Ibid.

The author would like to thank Cristen Razarri, USF MBA 2004, for her research assistance. 